\title{
A SOLUÇÃO DE CONFLITOS DENTRO E FORA DO PROCESSO POR MEIO DA MEDIAÇÃO NO ORDENAMENTO JURÍDICO BRASILEIRO: UMA NECESSÁRIA CONTRIBUIÇÃO DO PENSAMENTO DE EMMANUEL LEVINAS SOBRE A JUSTIÇA E A ALTERIDADE PARA A REFLEXÃO A RESPEITO DA MEDIAÇÃO
}

\author{
THE SOLUTION OF CONFLICT WITHIN AND OUTSIDE THE PROCESS THROUGH \\ MEDIATION IN THE BRAZILIAN LEGAL SYSTEM: A NECESSARY CONTRIBUTION \\ OF THE THOUGHT OF EMMANUEL LEVINAS ABOUT JUSTICE AND OTHERNESS \\ TO REFLECTION ABOUT THE MEDIATION
}

\begin{abstract}
Alessandra Garcia Marques
Mestranda em Direito Constitucional pelo IDP. Graduada em História pela Universidade Federal de Uberlândia. Graduada em Direito pela Universidade Federal de Uberlândia. Pós-graduada em Direito Sanitário pela UNB, em Direito Tributário pela UCAM e em Direito Penal e Processual Penal pela UCAM. Atualmente é Promotora de Justiça titular da Promotoria de Justiça de Defesa do Consumidor do Ministério Público do Estado do Acre. Ministra cursos de Direito do Consumidor na Escola da Magistratura do Acre ESMAC. Ministra curso na Escola Nacional de Defesa do Consumidor do Ministério da Justiça - ENDC. E-mail: amarques@mpac.mp.br
\end{abstract}

Recebido em: 07/06/2016

Aprovado em: 12/07/2016

Doi: $10.5585 /$ rdb.v15i6.406

RESUMO: O presente artigo busca compreender em que medida a mediação, compreendida a partir do aparato teórico ofertado pelo pensamento de Emmanuel Levinas sobre justiça e alteridade, pode funcionar efetivamente como mecanismo adequado de solução de problemas, de controvérsias e de conflitos, considerando que o instituto ganhou enorme importância no ordenamento jurídico brasileiro, a partir da Lei de Mediação e, especialmente, do advento do novo Código de Processo Civil, que se abriu para os mecanismos adequados ou alternativos de solução dos conflitos tendo a Constituição da República como fundamento. Para tanto, neste trabalho optou-se por realizar a análise conceitual da mediação, demonstrando sua importância, conceito, finalidade, método e vinculação, ocupando-se, adiante, de analisar como as concepções de justiça e de alteridade de Emmanuel Levinas são importantes para a mediação, porque permitem a potencialização de seu uso precisamente em razão de sua finalidade maior de pacificação social qualificada. Tendo, portanto, como aparato teórico o pensamento levinasiano, ao final, é possível concluir que trazer a justiça para o Direito e compreender a justiça enquanto uma justiça sociopolítica partindo da ética da alteridade possibilita potencializar a mediação, permitindo a tutela dos direitos dentro e, sobretudo, fora do processo, com vistas à pacificação social, sendo que, para que isso seja possível, ou seja, para que a mediação sirva para que de fato o problema, a controvérsia ou o conflito seja solucionado é necessário que nela o sujeito perceba a subjetividade de outrem e respeite-a, de forma e não reduzir essa subjetividade à subjetividade de si mesmo. 
Palavras-chave: Mediação. Alteridade. Justiça. Emanuel Levinas. Acesso à justiça.

\begin{abstract}
This article intends to understand how the mediation, understood through the Emmanuel Levinas' thought about justice and otherness, can works indeed as appropriate mechanism of solution of problems, controversies and conflicts, considering that the institute conquered enormous importance in Brazilian Legal System, starting from the Mediation Act and, especially, of the coming of the new Code of Civil Process, that opened up for the appropriate or alternative mechanisms of solution of the conflicts considering the Constitution of the Republic as foudation. For this this work opted to accomplish the conceptual analysis of the mediation demonstranting its importance, concept, purpose, method and linking, treating of analyzing afterwards how the Levinas' conceptions of justice and otherness are importante for the mediation, because they allow the strengthening of its use precisely in reason of its larger purpose of qualified social pacification. Therefore, having as theoretical apparatus the Levinas' thought, at the end, it can be conclude that to bring the justice to the Law and understand the justice as a sociopolitical justice from the ethics of alterity enables leveraging the mediation, allowing the protection of rights inside and especially outside of the process, for the purpose of social pacification, but, for this to be possible, in the other words, for the mediation to resolve the problem, controversy or conflict is necessary that in mediation the subject understands the subjectivity of other and respect it, and do not reduce this subjectivity to the subjectivity of oneself.
\end{abstract}

Keywords: Mediation. Alterity. Justice. Emmanuel Levinas. Acess to justice.

SUMÁRIO: Introdução; 1 A cultura da judicialização e da adversariedade no Brasil e o esforço do novo Código de Processo Civil em favor da autocomposição; 2 A mediação enquanto meio de solução consensual de conflitos no ordenamento jurídico brasileiro; 3 Mediação e acesso à justiça; 4. A contribuição do pensamento de Emmanuel Levinas sobre alteridade e justiça para a mediação; Conclusão; Referências.

\title{
INTRODUÇÃO
}

No ano de 1985, a Corte de Columbia, nos Estados Unidos, instituiu o Multi-door courthouse, um sistema de triagem preliminar de litígios, a fim de que fosse possível analisar, para cada caso, qual seria o meio mais adequado de solução do conflito existente. Essa foi a primeira vez em que métodos ditos alternativos ou adequados de solução de conflitos foram aplicados oficialmente.

Foi, contudo, na década de 1970, que o Professor Frank Sander de E.A. da Harvard Law School articulou, pela primeira vez, o conceito de sistema multiportas, precisamente no ano de 1976, em uma conferência denominada Conferência Nacional sobre as Causas da Insatisfação Popular com a Administração da Justiça, realizada por força de convocação feita pelo Chefe de Justiça Warren Burger, para resolver os problemas enfrentados pelos juízes na administração da justiça estadunidense (KESSLER; FINKELSTEIN, 1998).

Naquela quadra da história, foi vislumbrada a ideia de que, no futuro, a solução dos conflitos passaria por uma grande variedade de opções ao jurídico contencioso ${ }^{1}$, à jurisdição

\footnotetext{
${ }^{1}$ Hoje, inclusive, fala-se, além da negociação, da conciliação, da mediação e da arbitragem no processo restaurativo e nas convenções processuais como mecanismos adequados de solução de conflitos.
}

Revista de Direito Brasileira | São Paulo, SP | v. 15 | n. 6 | p. 200 - 222 | set./dez. 2016 
prestada pelo estado propriamente, incluindo dentre as ditas opções a mediação, a conciliação, a arbitragem e o "ombudspeople", ou seja, por meio dos denominados ADR ou Alternative Dispute Resolution (KESSLER; FINKELSTEN, 1998, p. 577).

Foram os benefícios que a ideia de sistema multiportas ofertava já naquele momento aos cidadãos os responsáveis por fazerem o Chefe de Justiça Moultrie, da Corte do Distrito de Columbia, entender o real valor da disponibilidade de formas distintas de solução de conflitos naquele momento chamadas de alternativas para a solução de litígios.

A ideia de sistema multiportas que foi experimentada em Columbia, segundo estudiosos, tem como objetivos o incremento da consciência dos cidadãos sobre os diferentes mecanismos de solução de conflitos disponíveis na comunidade; o auxílio aos cidadãos para que possam identificar o locus apropriado para resolver suas disputas; o reforço da coordenação de serviços oferecidos por diversos mecanismos de solução de conflitos; o incremento do conhecimento sobre as técnicas apropriadas para a avaliação de casos e identificação das vias próprias para o processamento desses e, por fim, a promoção da replicação dos mecanismos de avaliação de casos de maneira centralizada (RIEGO; LILLO, 2014).

No Brasil, em que pese já existissem a Lei Federal n. ${ }^{\circ}$ 9.307/1996, que tratou da arbitragem, lei essa alterada, em parte, pela Lei Federal n. ${ }^{\circ}$ 13.129/2015, e o Código de Processo Civil de 1973, o qual contemplou a conciliação, com algumas mudanças no tratamento dessa ao longo do tempo, foi a Lei Federal n. . $^{2} 3.140$ de 2015 que inovou consideravelmente ao tratar de modo detalhado da mediação, sendo que, ademais, é impossível não se observar que a maior novidade introduzida legislativamente no ordenamento jurídico brasileiro foi o Código de Processo Civil de 2016, que entrou em vigor em 18 de março de 2016 contemplando os métodos adequados ou alternativos de solução de conflitos.

No âmbito do processo coletivo, o sistema processual já dispunha, desde 1985, de técnicas extraprocessuais de tutela coletiva, que podem possibilitar, sobretudo, a tutela coletiva especialmente fora do processo.

Ademais, é pertinente apontar que o Conselho Nacional de Justiça e o Conselho Nacional do Ministério Público, por meio de duas importantes resoluções, respectivamente a Resolução n. ${ }^{\circ} 125$, de 29 de novembro de 2010, e a Resolução n. ${ }^{\circ} 118$, de $1^{\circ}$ de dezembro de 2014, trataram de explicitar políticas públicas destinadas à autocomposição.

Assim, a primeira Resolução diz respeito à Política Judiciária Nacional de tratamento adequado dos conflitos de interesses no âmbito do Poder Judiciário, enquanto a segunda dispõe sobre a Política Nacional de Incentivo à Autocomposição no âmbito do Ministério Público, sendo que a solução dos conflitos pelas próprias partes, por meio dessa derradeira, é estimulada, inclusive, no bojo dos processos em que o Ministério Público atua como custos constitutionis, incluindo-se nessa expressão também a função de fiscal da lei. Não fosse o suficiente, o Conselho Nacional da Magistratura aprovou, em 2016, a Resolução n. ${ }^{\circ} 225$, de 31 de maio, que trata da Política Nacional de Justiça Restaurativa no âmbito do Poder Judiciário, um outro passo importantíssimo dado no sentido de mudança de paradigma do tratamento pelo estado-juiz das relações decorrentes de práticas que se subsumem a delitos.

Dispondo o ordenamento jurídico tradicionalmente sobre a conciliação e a arbitragem, o fato é que, a partir do advento do novo Código de Processo Civil, a mediação ganhou enorme destaque, devendo ser seriamente incentivada, robustecida, em razão de sua finalidade, de seu método e vinculação, tal como no presente trabalho será demonstrado. Isso demanda, antes de tudo, que a mediação seja devidamente compreendida, porque não pode ser confundida com a conciliação, da qual se distingue claramente, e, sobretudo, porquanto sua finalidade maior é uma pacificação social que se pode dizer qualificada.

Mediação e a conciliação, aliás, são mecanismos de autocomposição de problemas, de controvérsias e de conflitos que só aparentemente são parecidos. Isso porque, enquanto a 
mediação é uma forma de solução de conflitos em que uma terceira pessoa, neutra e imparcial, deve atuar como facilitadora da reconstrução da relação entre as partes por meio do restabelecimento do diálogo entre elas, para que as partes construam, com autonomia e solidariedade, a melhor solução para ambas naquele caso, compondo de modo a evitar futuros conflitos, a conciliação vem a ser um mecanismo utilizado em conflitos mais simples ou restritos, nos quais o ponto central está claramente identificado, de sorte que o terceiro, que atua como facilitador, pode adotar uma posição mais ativa, porém neutra com relação ao conflito e imparcial, sendo, assim, um processo consensual breve. Enquanto, portanto, a conciliação busca a paz social dentro dos limites possíveis, a mediação tem ambições profundas de pacificação social, visando, assim, uma forte harmonização social e a restauração da relação entre as partes.

Sucede que é precisamente aquilo que distingue a conciliação da mediação que interessa ao presente trabalho, porquanto, em que pese ambas sejam técnicas orientadas por princípios como os da informalidade, simplicidade, economia processual, celeridade, oralidade e flexibilidade processual, elas distinguem-se claramente quanto ao método, à vinculação e, especialmente, à finalidade.

A mediação é, diferentemente da simples conciliação, o espaço para o debate profundo entre os envolvidos, pois é na mediação que se objetiva, antes de tudo, resgatar o diálogo entre as partes, que finalmente darão a solução para o caso que melhor aproveite a elas, com foco na restauração propriamente da relação que antes existia. O que importa verdadeiramente na mediação, antes da solução do caso, é que seja aberto um espaço para o debate, para que seja possível o restabelecimento da comunicação entre as partes, a restauração e a preservação do relacionamento entre elas, devendo-se assegurar que novos conflitos não voltem a ocorrer no futuro, quando também pode ser percebida a ocorrência de inclusão social ligada à participação de particulares na realização da justiça, e, também, a pacificação social decorrente da dissolução de litígios e da construção de consenso (TARTUCE, 2008).

Quanto ao método, a mediação também se diferencia da conciliação completamente, pois, qualquer que seja o modelo de mediação ${ }^{2}$ adotado, o método da mediação objetivará a consecução dos fins buscados pelo mecanismo, que são distintos dos fins perseguidos pela conciliação.

Dessa sorte, a mediação objetiva resolver, de modo mais amplo possível, o conflito entre os envolvidos, enquanto a conciliação pretende solucionar o conflito nos termos apresentados pelos envolvidos, daí porque a conciliação adequa-se às relações que não se perpetuam no tempo e para situações em que existe uma identificação evidente do problema, quando o problema é verdadeiramente a razão do conflito. Já na mediação é sobretudo a falta de comunicação que impede o resultado positivo.

Além do mais, as funções de conciliador e de mediador são distintas, porquanto aquele pode sugerir às partes os termos em que o acordo pode ser realizado, dialogando de modo abeto a respeito desse, ao passo que o mediador assim não pode agir, devendo ele somente assistir as partes e facilitar a sua comunicação, para favorecer a obtenção de um acordo que atenda aos envolvidos.

A vinculatividade também distingue a conciliação da mediação, porque, quando buscada em juízo, aquela está relacionada ao Poder Judiciário, sendo realizada por juiz togado, por juiz

\footnotetext{
${ }^{2}$ Em que pese não seja objeto do presente trabalho tratar dos modelos de mediação propriamente, é válido apontar que, dentre esses, pode ser claramente reconhecido o modelo de Luiz Alberto Warat, que pretende mediar a partir da psicoterapia do reencontro ou do amor perdido, ademais, há o modelo Tradicional-Linear de Harvard ou Programa de Negociação da Escola de Harvard, conhecido como mediação satisfativa; o modelo Circular- Narrativo de Sara Cobb, que é centrado na ideia de comunicação circular e lança mão da teoria dos sistemas de Luhmann; e o modelo Transformativo de Bush e Folger, que é focado no aspecto relacional da comunicação (GOULART; GONÇALVES, 2016).
} 
leigo ou por alguém com função de conciliador, no bojo do processo, conforme previsto na legislação processual. Já a mediação, que pode acontecer dentro ou fora do processo, consiste numa atividade propriamente, tanto que, mesmo se realizada no processo, o mediador tem que se registrar no tribunal para o fim de ser indicado para atuar nos conflitos levados ao conhecimento do Poder Judiciário.

No presente trabalho, busca-se compreender em que medida a mediação, que não se confunde com a simples conciliação, compreendida a partir do aparato teórico ofertado pelo pensamento de Emmanuel Levinas sobre justiça e alteridade, pode funcionar efetivamente como mecanismo adequado de solução de problemas, de controvérsias e de conflitos, considerando que o instituto ganhou enorme importância no ordenamento jurídico brasileiro, a partir da Lei de Mediação e, especialmente, do advento do novo Código de Processo Civil, que se abriu para os mecanismos adequados de solução dos conflitos tendo a Constituição da República como fundamento.

Nesse sentido, para que o trabalho seja efetivado, buscou-se, enquanto metodologia, realizar a análise conceitual da mediação, demonstrando sua importância, conceito, finalidade, método e vinculação, ocupando-se, em seguida, de analisar como as concepções de justiça e de alteridade de Emmanuel Levinas são importantes para a mediação, porque possibilitam a potencialização de seu uso especificamente em razão de sua finalidade maior de pacificação social qualificada.

É importante destacar que, em razão da finalidade, do método, da vinculatividade e também da importância de um mecanismo como a mediação para um país em que a litigiosidade atinge números estarrecedores e deixa evidente a incapacidade do Poder Judiciário de tudo decidir, que o atual trabalho busca refletir sobre a contribuição que o pensamento de Emmanuel Levinas a respeito da justiça e da alteridade pode oferecer para que a mediação funcione efetivamente como mecanismo adequado de solução de problemas, de controvérsias e de conflitos.

\section{A CULTURA DA JUDICIALIZAÇÃO E DA ADVERSARIEDADE NO BRASIL E O ESFORÇO DO NOVO CÓDIGO DE PROCESSO CIVIL EM FAVOR DA AUTOCOMPOSIÇÃO}

Segundo o Justiça em Números de 2015 (CONSELHO..., 2015), referente ao ano de 2014, o número de processos em tramitação na justiça brasileira era de 99,7 milhões de processos. Embora ainda não tenha o Conselho Nacional de Justiça, responsável pelo Justiça em Números, divulgado os dados de 2016, que tomam como ano-base o ano de 2015, é fácil concluir que já há mais de 100 milhões de processos em tramitação no Judiciário brasileiro em 2016.

Esse número de processos mencionado, segundo o CNJ, é o resultado da soma dos 28,9 milhões de processo novos registrados em 2014 e dos 70, 8 milhões de processos que se encontravam pendentes também no ano de 2014.

Ao mesmo tempo o Instituto Brasileiro de Geografia e Estatística, em 2015, informou que o Brasil tinha uma população de 204.450.649 habitantes (INSTITUTO..., 2015).

Até 2015, portanto, é possível afirmar que existe um processo para cada dois brasileiros, o que possibilita dizer de outro modo que, levando em consideração o fato de que num processo existem pelo menos duas partes, autor e réu, toda a população brasileira está ligada a pelo menos um processo, ou seja, há processos para toda a população brasileira.

Desse modo, deve-se facilmente conceber que esses 100 milhões de processos são incompatíveis com a estrutura do poder judiciário, com o número de juízes existentes no país, o que é, aliás, fato público e notório, e com a boa realização da justiça no tempo devido. 
Com base nesses dados, é perfeitamente possível afirmar que os métodos adequados ou alternativos de solução de conflitos são imprescindíveis ao acesso à justiça no Brasil tanto quanto é fundamental uma mudança na cultura adversarial e altamente litigiosa, sem se desconsiderar que outro grande desafio diz respeito ao fato de que só em 2014, 15\% dos 23,7 milhões de ações que ingressaram na Justiça dizem respeito às matérias tributárias, previdenciárias ou de Direito Público (CONSELHO...., 2015), o que significa dizer que o comportamento do estado brasileiro é a maior causa do excesso de processos em andamento na justiça do país.

Nesse cenário, é importante firmar que os mecanismos de solução adequada ou alternativa dos conflitos encontram, antes de tudo, amparo constitucional.

A Constituição da República, que em seu preâmbulo diz ser um dos valores supremos da sociedade o bem-estar, e que segue afirmando que a sociedade fraterna, pluralista e sem preconceitos está fundada na harmonia social e comprometida, interna e externamente, com a solução pacífica das controvérsias, dispõe, no seu art. $4^{\circ}$, inciso VII, que, nas relações internacionais, a República Federativa do Brasil é regida, dentre outros princípios, pela solução pacífica dos conflitos.

A respeito da eficácia normativa do preâmbulo, como explica Lucena Filho (2012), que vislumbra a ideia de que as soluções consensuais de conflitos encontram fundamento também no preâmbulo da Constituição de 1988, não há consenso doutrinário. Sobre tanto, em linhas gerais, para alguns o preâmbulo é irrelevante juridicamente, porque estaria apenas no âmbito da política, sendo que para outros é compreendido como possuidor de relevância jurídica indireta, ao fazer parte das características da Constituição sem com suas normas se confundir, ao passo que existem aqueles que defendem a tese da plena eficácia jurídica do preâmbulo, que teria assim a mesma eficácia das normas constitucionais.

Lucena Filho (2012), que, como no presente trabalho, despreza a ideia de irrelevância jurídica total do preâmbulo, demonstra que o Supremo Tribunal Federal tem mudado seu posicionamento sobre a eficácia normativa do mencionado preâmbulo, de modo que, se em suas primeiras manifestações, o preâmbulo estava alheio ao Direito, mais recentemente, esse posicionamento tem sido abrandado no sentido de considerar o preâmbulo como um argumento interpretativo, um vetor axiológico de interpretação.

Ademais, a interpretação do inciso VII do art. $4^{\circ}$ da Constituição da República deve levar à conclusão de que internamente a solução pacífica dos conflitos deva ser também um princípio importante, o qual impõe ao poder público o estabelecimento de políticas públicas voltadas para esse tipo de solução dos conflitos. Essa interpretação obviamente encontra apoio no fato de que o Brasil não poderia priorizar a solução pacífica de conflitos em nível internacional e, internamente, priorizar modos distintos de solução (LUCENA FILHO, 2012).

E isso não é tudo, porque, no art. $3^{\circ}$, inciso IV, da Constituição de 88 , o constituinte estabeleceu que a promoção do bem de todos é um dos objetivos fundamentais da República Federativa do Brasil, o que, evidentemente, exige políticas públicas que previnam conflitos e que estimulem a pacificação desses, sendo que, no art. 193, dispõe a Carta Política que a ordem social tem como um de seus primados o bem-estar, o que igualmente exige políticas públicas preventivas de conflitos e que promovam a solução pacífica desses. Nesse sentido é claro que a solução pacífica dos conflitos será tanto mais efetiva quanto mais efetiva for também a solução consensual desses.

A esta altura, é inevitável festejar, em nível infraconstitucional, o reforço que os métodos adequados ou alternativos de solução de conflitos ganharam com o advento do novo Código de Processo Civil, fato esse que, aliás, foi antecedido pela Lei da Mediação.

Diz o $\S 3^{\circ}$ do art. $3^{\circ}$ do Código de Processo Civil, Lei Federal n. ${ }^{\circ}$ 13.105/2015:

Art. $3^{\circ}$ Não se excluirá da apreciação jurisdicional ameaça ou lesão a direito. 
$\S 1^{\circ}$ É permitida a arbitragem, na forma da lei.

$\S 2^{\circ}$ O Estado promoverá, sempre que possível, a solução consensual dos conflitos

$\S 3^{\circ}$ A conciliação, a mediação e outros métodos de solução consensual de conflitos

deverão ser estimulados por juízes, advogados, defensores públicos e membros do Ministério Público, inclusive no curso do processo judicial.

A conciliação, que já era tratada o Código de Processo Civil revogado, mereceu novo tratamento no Código de Processo Civil que entrou em vigor em 2016. Já em seu art. 165 o novo Código de Processo Civil dispõe que deverão ser criados centros judiciários de solução de conflitos, os quais deverão realizar sessões e audiências de conciliação e mediação e desenvolver programas de auxilio, orientação e estímulo à autocomposição.

Aliás, o novo Código de Processo Civil, que trouxe capítulo específico sobre mediação e conciliação, tratou dessa última de modo muito mais consistente do que o Código de Processo Civil de 1973, e também dispôs de modo inovador sobre a mediação nos arts. 165, 166 a 175 , 250, 303, 308, 319, 320, 334, 340, 694, 695 e 696.

No novo Código de Processo Civil também foram positivados os princípios que orientam a conciliação e a mediação, quando, no art. 166, caput, foi dito que "A conciliação e a mediação são informadas pelos princípios da independência, da imparcialidade, da autonomia da vontade, da confidencialidade, da oralidade, da informalidade e da decisão informada."

Não bastasse o tratamento inovador dado à mediação e à conciliação, o novo Código de Processo Civil, no art. 175, abre-se ainda mais para a solução pacífica e consensual dos conflitos, quando não exclui outras formas de conciliação e de mediação que denomina extrajudiciais ligadas a órgãos institucionais ou efetivadas por meio de profissionais independentes, conforme lei específica, e ainda diz que os dispositivos sobre a conciliação e a mediação são aplicáveis às câmaras privadas de conciliação e mediação.

Segundo o art. 250, inciso IV, do novo Código de Processo Civil, na citação por oficial de justiça o mandado judicial deverá conter, dentre outros requisitos, a intimação do citando para comparecer à audiência de conciliação ou de mediação, com referência de dia, hora e lugar, acompanhado de advogado ou de defensor público.

Como no novo Código de Processo Civil, a tutela antecipada satisfativa ganhou autonomia procedimental, concedida essa tutela, o autor deverá, no prazo de 15 dias ou em outro prazo maior, aditar a inicial, complementando sua argumentação, juntando novos documentos e confirmando o pedido de tutela final, sendo que o réu será citado e intimado para a audiência de conciliação ou de mediação na forma do art. 334 do Código de Processo Civil, quando, não ocorrendo autocomposição, o prazo para contestação se contado na forma do at. 335.

De mesmo modo, no novo Código de Processo Civil, efetivada a tutela cautelar requerida de forma antecedente, o pedido principal deverá ser formulado em 30 dias, nos mesmos autos, quando as partes serão intimadas para audiência de conciliação ou de mediação, conforme dispõe o art. $308, \S 3^{\circ}$. Nesse caso, inexistindo a solução do conflito pelas partes, será contado prazo para contestação.

Na sistemática do novo Código de Processo Civil, inclusive, o autor deverá indicar na inicial, nos termos do art. 319, inciso VII, a opção pela realização ou não de audiência destinada à conciliação ou à mediação.

E, se a inicial contiver os requisitos essenciais e não for o caso de improcedência liminar do pedido, será pelo juiz designada audiência de conciliação ou de mediação com antecedência mínima de 30 dias, devendo o réu ser citado com pelo menos 20 dias de antecedência, de acordo com o art. 334 do Código de Processo Civil. Nessa audiência atuará, onde houver, o conciliador ou mediador, contudo, mesmo estando prevista a possibilidade de realização de mais de uma 
sessão de conciliação ou de mediação, não poderá haver entre a primeira sessão e as outras um prazo superior a 2 meses, devendo a intimação do autor para a audiência ser feita na pessoa de seu advogado.

A audiência, nos termos do art. 334, $\S 4^{\circ}$, do Código de Processo Civil, não acontecerá se ambas as partes manifestarem desinteresse na autocomposição ou quando essa não for admitida. Para tanto, o autor deve dizer na inicial que não pretende ver o conflito solucionado pelas próprias partes, ao passo que o réu deverá fazê-lo, por meio de petição a ser apresentada no prazo de 10 dias, que serão contados da data da audiência. Se houver litisconsórcio, todos deverão manifestar ausência de interesse na audiência.

Não bastasse tanto, o novo Código de Processo Civil, em seu art. 334, $\S 7^{\circ}$, inova também ao possibilitar a audiência de conciliação ou de mediação por meio eletrônico, o que, especialmente no caso da mediação, pode ser bastante criticável, tendo em vista o modelo de mediação adotado e, sobretudo, a finalidade propriamente da mediação.

O sistema levou tão a sério a autocomposição que, no art. $334, \S 8^{\circ}$, do Código de Processo Civil, fixou multa para o autor ou réu que não comparece à audiência injustificadamente, dizendo configurar ato atentatório à dignidade da justiça, sendo que, na audiência, as partes devem estar acompanhadas de advogado ou defensor público, podendo constituir representantes para negociar e transigir, por meio de procuração específica.

Além disso, se houver alegação de incompetência relativa ou absoluta, a audiência de conciliação ou de mediação será suspensa, de forma que, após a definição da competência, deverá ser designada nova data para que a audiência que objetiva a solução do conflito pelas partes ocorra, conforme dispõe o art. 340, $\S 4^{\circ}$, do Código de Processo Civil.

Destaque especialíssimo deu o novo Código de Processo Civil à solução consensual do conflito, quando cuidou de reforçar a importância da autocomposição pela conciliação ou pela mediação, nos artigos 694, 695 e 696. Aqui, para fortalecer a solução consensual nas ações de família a contrafé não deve sequer ser encaminhada inicialmente para o réu, que será citado para comparecer à audiência de conciliação ou de mediação, devendo o mandado conter somente os dados necessários à audiência. Ademais, nesta audiência as partes não estarão acompanhadas de advogado ou de defensor público, e a audiência poderá ser dividida em tantas sessões quantas forem necessárias, o que objetiva fomentar a solução consensual, ficando resguardadas, todavia, as providências que objetivam evitar que o direito pereça, tal como dispõe o art. 696 do Código de Processo Civil.

E não foi tudo, porque o novo Código de Processo Civil, além de tratar da conciliação e da mediação em um capítulo inteiro e de prever que a tentativa de autocomposição anteceda a resposta do réu (artigos 334 e 695) com a finalidade de incentivar a solução do conflito pelas partes, ainda possibilita a homologação de acordo extrajudicial de qualquer natureza, no art. 515, inciso III; admite que no acordo judicial seja inserida matéria alheia ao objeto litigioso, no art. $515, \S 2^{\circ}$; e inova ao permitir acordos processuais atípicos, que digam respeito ao processo e não ao objeto litigioso, o que faz no art. 190 (DIDIER JR., 2016).

Vê-se que, enquanto o Código de Processo Civil de 1973 não dispensou um artigo à mediação e dispôs sobre a conciliação somente nos artigos 277, 278, 331, 447, 448 e 449, o novo Código de Processo abriu-se para os meios consensuais de solução de conflitos e tratou de modo detalhado da conciliação e da mediação.

Aliás, o velho Código de Processo Civil, a partir de 1995, basicamente admitia que a conciliação fosse feita a qualquer tempo no processo, sendo que no procedimento sumário havia uma audiência de conciliação que deveria ser realizada em 30 (trinta) dias, quando, se na audiência não houvesse conciliação, o réu apresentaria defesa.

Contudo, na redação original, o Código de Processo Civil de 1973 dava pouquíssimo destaque à conciliação, quando a seu respeito apenas dizia que:

Revista de Direito Brasileira | São Paulo, SP | v. 15 | n. 6 | p. 200 - 222 | set./dez. 2016 
Art. 447. Quando o litígio versar sobre direitos patrimoniais de caráter privado, o juiz, de ofício, determinará o comparecimento das partes ao início da audiência de instrução e julgamento.

Parágrafo único. Em causas relativas à família, terá lugar igualmente a conciliação, nos casos e para os fins em que a lei consente a transação. Art. 448. Antes de iniciar a instrução, o juiz tentará conciliar as partes. Chegando a acordo, o juiz mandará tomá-lo por termo.

Art. 449. O termo de conciliação, assinado pelas partes e homologado pelo juiz, terá valor de sentença.

Vê-se que, em 1973, a conciliação seria objeto de tentativa apenas no início da audiência de instrução de causas que versavam sobre direitos patrimoniais de caráter privado, sendo que em ações de família teria lugar nos casos em que a lei admitisse transação.

Após sua entrada em vigor, o Código de Processo Civil de 1973 sofreu duas alterações no tocante à conciliação, é de se dizer, em 1994 foi alterado para prever no art. 331 uma audiência de conciliação que deveria ocorrer no prazo máximo de 30 (trinta) dias, para as causas que tratavam de direitos disponíveis, ao passo que, em 2002, esse dispositivo foi modificado para prever uma audiência preliminar, na qual, não obtida a conciliação, o juiz deveria fixar os pontos controvertidos, decidir as questões processuais pendentes e determinar as provas a serem produzidas, designando, também, audiência de instrução e julgamento, quando necessária.

Desde 1994, por força da Lei Federal n. ${ }^{\circ}$ 8.952, também ficou previsto no art. 125, inciso IV, do Código de Processo Civil de 1973, que a ao juiz competia tentar conciliar as partes a qualquer tempo.

Sob os auspícios do velho Código de Processo Civil, portanto, tentar a conciliação era dever do magistrado a qualquer tempo no processo, conforme o art. 125, IV, sendo que o art. 331 estabelecia para o procedimento ordinário uma audiência preliminar à fase de instrução probatória, enquanto os artigos 447 e 448 previam uma tentativa de conciliação no início da audiência de instrução.

É fácil notar, por tudo isso, que nem mesmo à conciliação o antigo Código de Processo Civil deu a devida ênfase, o que evidentemente contrasta com o que se pode chamar de a judicialização de tudo quanto há, que atualmente ocorre no Brasil.

\section{A MEDIAÇÃO ENQUANTO MEIO DE SOLUÇÃO CONSENSUAL DE CONFLITOS NO ORDENAMENTO JURÍDICO BRASILEIRO}

É necessário dizer a esta altura que a terminologia Alternative Dispute Resolution $A D R$, que no Brasil foi traduzida para meios alternativos de solução de conflitos, sofreu críticas fundamentadas em dois aspectos importantes. Num primeiro, diz-se que a terminologia fundada numa negativa ressalta o fato dos meios não serem de adjudicação estatal, de sorte que acaba por não destacar o que se quer, ou seja, o que realmente são os ditos meios. O destaque para a negativa acaba, assim, por fazer com que, para conhecer tais meios seja necessário conhecer os meios estatais que seriam principais. Num segundo aspecto, a terminologia implica o estabelecimento da ideia de principal e de alternativo propriamente, o que desqualifica os meios ditos alternativos. Em face da crítica, passou-se a atribuir ao $A$ do $A D R$, segundo Lee (2012), ao invés da palavra alternativo, a palavra apropriado ou adequado.

Adiante, ainda no curso da evolução do termo $A D R$, passou-se a atribuir ao $A$ a palavra amicable, ou seja, amigável, palavra essa que, embora ressalte a ideia da maioria dos meios, 
tende a excluir a arbitragem ${ }^{3}$, abrangendo, de outra sorte, a negociação, a conciliação e a mediação, de forma que prevaleceu a ideia de meios apropriados ou adequados de solução de conflitos (LEE, 2012).

De qualquer forma, os problemas, as controvérsias ou conflitos podem ser solucionados pela autotutela, pela autocomposição ou pela heterocomposição, sendo que as duas primeiras são pacificamente denominadas de equivalentes jurisdicionais, juntamente com as decisões dos tribunais administrativos (DIDIER JR., 2016).

A distinção entre problema, controvérsia e conflito é feita por Moraes (MANUAL..., 2015, p. 23), quando explica que a referida distinção é necessária, porque o conflito ocorre quando as partes possuem interesses ou posições contrárias, sendo que uma resiste, enquanto a controvérsia é caracterizada também pela existência de posições ou de interesses antagônicos sem que, contudo, exista resistência. Já o problema ocorre, quando não há conflito a ser solucionado, sendo muito comum nos casos em que se discute a prevenção, por exemplo.

No ordenamento jurídico brasileiro a autotutela foi historicamente sendo abandonada, de modo que hoje são poucos os casos no direito civil e no direito penal em que a autotutela é admitida, por consistir numa forma egoísta de solução de um conflito, que se caracteriza pela imposição da vontade de uma das partes, em detrimento do interesse do outro. Aliás, o exercício da autotutela é crime no ordenamento jurídico brasileiro, pois pode subsumir-se ao crime de exercício arbitrário das próprias razões ou até mesmo ao crime de abuso de autoridade, conforme o sujeito ativo. No direito penal a autotutela toma a forma de legítima defesa, enquanto no direito civil há o direito de retenção, a legítima defesa no caso de turbação e o desforço imediato no caso do esbulho. Ademais, o direito de greve e a autoexecutoriedade dos atos administrativos são casos de autotutela.

Quando se trata da autocomposição, está-se a falar a respeito da solução de conflito à qual as partes conflitantes chegam sem a imposição de uma vontade sobre a outra, que pode ocorrer dentro ou fora do processo. Pode ser que uma das partes envolvidas no conflito sacrifique total ou parcialmente seu interesse em favor da outra parte ou que seja construído um acordo entre ambas as partes.

De acordo com Didier Jr. (2016), que defende a existência de um princípio do estímulo da solução por autocomposição, essa é gênero que tem como espécies a transação, em que as partes fazem concessões mútuas, e a submissão, na qual uma parte simplesmente se submete à pretensão da outra, abrindo mão de seus interesses, submissão essa que, no processo, se feita pelo autor é renúncia, e, se feita pelo réu é reconhecimento da procedência do pedido. Já a heterocomposição ocorre quando a decisão sobre o conflito é dada por terceiro imparcial, que tem autoridade para impor uma solução para as partes em conflitos, o que acontece, portanto, no caso da jurisdição e da arbitragem. ${ }^{4}$

A solução consensual de conflitos que não seja dada pelo estado-juiz no processo individual pode ocorrer por meio da negociação, da conciliação, da mediação e da arbitragem, sendo que enquanto a arbitragem ocorre fora do processo, os três outros mecanismos podem acontecer antes, durante ou após o processo.

A negociação é realizada diretamente pelos envolvidos no conflito, podendo, assim, resultar na autocomposição ou, caso não exista sucesso, na utilização de outra técnica de solução do conflito pelas partes ou em técnica heterocompositiva. A negociação pode acontecer antes, durante ou depois do processo judicial ou de arbitragem

\footnotetext{
${ }^{3}$ Essa exclusão da arbitragem é parcial, porquanto, embora nesse mecanismo haja um terceiro imparcial que decidirá o conflito, não deixa de existir certo consenso entre as partes que, pelo menos, decidiram pela solução do caso por meio da arbitragem.

${ }^{4}$ Como a arbitragem não é objeto deste trabalho, não é pertinente discutir a controvérsia doutrinária que a cerca quanto à sua natureza jurídica, bastando apenas mencionar que essa existe.
}

Revista de Direito Brasileira | São Paulo, SP | v. 15 | n. 6 | p. 200 - 222 | set./dez. 2016 
A conciliação, cuja distinção em relação à mediação é bastante importante, tem indicação quando há uma identificação evidente do problema, da controvérsia ou do conflito, quando um desses é verdadeiramente a razão do conflito, sem que a questão seja propriamente a falta de comunicação que impede um resultado positivo na solução do caso. Diferentemente do mediador, inclusive, o conciliador tem a liberdade de sugerir uma solução, o que nunca pode ocorrer, em nenhum dos modelos de mediação, com esse mecanismo de solução de conflitos por meio do consenso das partes.

A mediação foi tratada inicialmente na Lei n. ${ }^{\circ} 13.140$, de 26 de junho de 2015 , e mais recentemente pelo novo Código de Processo Civil, como um dos mecanismos consensuais de solução de conflitos dentro ou fora do processo, é um ADR - Alternative Dispute Resolution, ou seja, mecanismo adequado ou alternativo de solução de conflitos.

Segundo Galanter (1989), os mecanismos adequados ou alternativos e solução de conflitos orientam-se por dois argumentos, um primeiro de produção, pois se prestam à obtenção de resultado célere e sem gasto de grande quantidade de recursos, e um segundo de qualidade, que diz respeito aos benefícios que os mecanismos podem representar.

A mediação, consoante Garcez (2003, p. 35) é um mecanismo adequado ou alternativo de solução de conflitos em que "...um terceiro, imparcial, auxilia as partes a chegarem, elas próprias, a um acordo entre si, através de um processo estruturado."

Segundo o art. $1^{\circ}$ da Lei Federal n. ${ }^{\circ} 13.140 / 15$, a mediação é "atividade técnica exercida por terceiro imparcial sem poder decisório, que, escolhido ou aceito pelas partes, as auxilia e estimula a identificar ou desenvolver soluções consensuais para a controvérsia."

A Lei de Mediação contemplou, inclusive, a autocomposição em caso de conflitos nos quais a pessoa jurídica de direito público for parte, quando, em seu art. 32, diz que a União, os Estados, o Distrito Federal e os Municípios deverão criar e manter câmaras de prevenção e resolução de conflitos na esfera administrativa. Essas câmaras deverão, conforme o referido dispositivo, dirimir conflitos no âmbito da própria administração, devendo também avaliar a admissibilidade de pedidos de resolução de conflitos entre particulares e a pessoa jurídica de direito público por composição e, ademais, promover, nos casos pertinentes, a celebração de termos de compromisso de ajustamento de conduta, esses são, segundo Gavronski (2010), técnicas extraprocessuais de tutela coletiva.

A mediação, enquanto mecanismo de solução de conflitos previsto e incentivado pelo novo Código de Processo Civil, além de absolutamente necessária ao ordenamento jurídico brasileiro em face da excessiva judicialização de problemas e de conflitos, interessa sobremaneira por ser um espaço para o debate, que possibilita, nos casos em que se apresenta como mecanismo adequado para a solução do conflito, trazer para o Direito a justiça por meio do consenso construído pelas partes, que restabelecem o diálogo, reconstroem relações, objetivando, ademais, não só solucionar o problema, a controvérsia ou conflito como também evitar que no futuro outros eventos conflituosos tornem a ocorrer.

A mediação é, sem dúvida, um mecanismo que tem por objeto resolver de modo mais amplo e profundo possível o conflito entre os envolvidos, o que faz dela um mecanismo ideal para solução de problemas, controvérsias e de conflitos ocorridos especialmente em relações que se perpetuam ao longo do tempo, nas quais, inclusive, não há uma identificação evidente do problema e existe uma falta de comunicação que impede o fim do conflito.

É pertinente dizer que, enquanto instrumento do estado democrático de direito, o processo possui um papel extremamente importante, que é o de resolver os conflitos e proporcionar a paz social, quando estabelece as normas jurídicas para as relações interpessoais por meio das decisões proferidas pelo Poder Judiciário, ao passo que a mediação, em face de suas finalidades, almeja alcançar o que pode ser chamado, como aqui agora é feito, de uma paz social qualificada. Tal se deve ao fato de que mais do que a resolução do caso concreto numa situação 
em que a relação plena entre as partes e seus sentimentos não sejam substancialmente importantes, à mediação interessa não apenas a relação jurídica entre as partes, pois o que com ela se objetiva é o estabelecimento do diálogo, o restabelecimento profundo da relação entre as partes e a construção de uma solução que possibilite a não reincidência de conflitos.

É certo, portanto, que na conciliação, na arbitragem e na jurisdição inexiste tamanha profundidade quanto ao propósito de solução dos conflitos como a que deve ser verificada na mediação.

\section{MEDIAÇÃO E ACESSO À JUSTIÇA}

Refletir sobre a mediação necessariamente significa reconhecer a importância da terceira onda de acesso à justiça tratada por Cappelletti e Garth (1988), ou seja, implica dizer que não basta ao acesso à justiça que esse seja meramente formal. É, pois, necessário que o acesso seja material, efetivo, concretizado no acesso a uma ordem jurídica justa, devendo-se pensar, ademais, no acesso efetivo ao processo estatal e no acesso à justiça numa perspectiva de acesso à justiça material fora do processo estatal, sabendo-se para tanto que, se o acesso à justiça formal relaciona-se historicamente com o estado liberal e com a igualdade formal, o acesso à justiça material liga-se ao estado social e à igualdade material (CAPPELLETTI; GARTH, 1988).

Neste ponto, é pertinente lembrar que, no Projeto Florença, Cappelletti e Garth (1988) revelaram a existência de três fatores desfavoráveis ao acesso à justiça. Um primeiro relacionado à situação econômica, ou seja, à pobreza e à falta de acesso à informação; um segundo que diz respeito à existência de interesses coletivos cuja titularidade não se coadunava com a titularidade individual e com a defesa tradicional desse derradeiro; e, por fim, um fator de natureza procedimental, caracterizado por uma preocupação com a efetividade da justiça sob o enfoque da qualidade propriamente dos resultados da atividade jurisdicional e também dos equivalentes jurisdicionais, de sorte que aqui existe uma preocupação com a solução dos conflitos dentro e também fora do processo.

É, portanto, no contexto da terceira onda de acesso à justiça que está inserido o debate acerca da mediação, tendo em vista a preocupação com a efetividade da justiça sob a perspectiva da qualidade dos resultados da jurisdição e dos mecanismos de solução de conflitos fora do processo. Nesse momento, portanto, entra em questão a efetividade da justiça relacionada à adequação das técnicas judiciais aos direitos em conflito e aos métodos de composição de conflitos dentro e fora do processo (CAPPELLETTI; GARTH, 1988).

Assim, a questão principal passa a ser o conflito e sua solução, quando, então, surgem incentivos aos métodos de composição de conflitos ditos não judiciais, como, aliás, tratam Cappelletti e Garth (1988).

Desse modo, na terceira onda de acesso à justiça é que se vê desenhada claramente a necessidade de se adequar as técnicas judiciais aos direitos em conflito, quando, ademais, a solução de conflitos passa a ser pensada não somente a partir do processo estatal. Tem-se, assim, a preocupação com o processo estatal, com a adequação das técnicas e a busca de resultados de qualidade e, ao mesmo tempo, com os mecanismos de solução de conflitos distintos da solução estatal dada por meio da jurisdição. Interessam, portanto, os conflitos e a composição desses.

A terceira onda de acesso à justiça ocupou-se do "novo enfoque do acesso à justiça", de acordo com Cappelletti e Garth (1988, p. 67), o qual se caracteriza especialmente pelo prestígio da autocomposição, até então bastante desprezada. Foi, aliás, da evidente dificuldade do estado de dar conta da solução de todos os conflitos que as soluções de conflitos fora do processo e da jurisdição passaram a ser consideradas enquanto justiça consensual. 
Nessa terceira onda, discute-se, na verdade, "uma ampla variedade de reformas, incluindo alterações nas formas de procedimento, mudanças na estrutura dos tribunais ou a criação de novos tribunais" (CAPPELLETTI; GARTH, 1988, p. 71).

Desse modo, há uma evidente percepção de que políticas públicas que incentivam meios adequados ou alternativos de solução de problemas, controvérsias ou conflitos, tais como a conciliação, a negociação, a arbitragem e a mediação, são necessárias.

No Brasil, nesse contexto, é possível mencionar a arbitragem para direitos disponíveis a transação para os delitos de menor potencial ofensivo e, no caso dos direitos coletivos, as técnicas de tutela coletiva fora do processo como o termo de compromisso de ajustamento de conduta (SANTIAGO, 2009). A essas derradeiras, inclusive, pode ser acrescentada a recomendação cumprida pelo recomendado.

Sobre a terceira onda, Cappelletti e Garth (1988) argumentam que são também necessárias reformas nos procedimentos, além de mudanças nos tribunais e criação de outros tribunais.

Nesse momento, para que se tenha ideia do que ocorreu por aqui, obviamente que não no mesmo tempo apontado no Projeto Florença, que não incluiu no estudo do acesso à justiça o Brasil, sob a ideia do que Cappelletti e Garth (1988, p. 67) chamaram de "novo enfoque do acesso à justiça", tal como antes mencionado, foram instituídos os Juizados de Pequenas Causas, que depois se transformaram nos Juizados Especiais Cíveis e Criminais dos Estados. Mais à frente, surgiram os Juizados Especiais Federais, quando houve, ademais, várias minirreformas do Código de Processo Civil que trataram, sobretudo, da adequação das técnicas processuais aos direitos a serem tutelados, ao passo que para a tutela coletiva também foram positivados o termo de compromisso de ajustamento de conduta e a recomendação, por exemplo.

Se o Projeto Florença tratou de três ondas renovatórias do processo civil, mais adiante Economides (1999) detectou a existência de uma quarta onda ligada aos operadores do direito, à formação e à qualidade desses, sendo que, mais recentemente, já se fala numa quinta onda, que estaria relacionada, segundo Junqueira (1996) à globalização e à justiça. Nessa derradeira onda, estaria em jogo a aplicação da justiça num mundo globalizado.

Como decorrência da importância que os conflitos e os meios alternativos ou adequados de solução desses necessariamente conquistaram, sobretudo diante da saturação do Poder Judiciário numa cultura altamente demandista e adversarial como a brasileira e da incapacidade do referido Poder de prestar a jurisdição de forma adequada, eficiente e no tempo devido a todos os que a procuram, as teorias do conflito passaram a ser do interesse dos que estudam o Direito 5 .

Essas teorias do conflito, todavia, não foram desenvolvidas pelo Direito, pois foram as Ciências Sociais, a Psicologia, a Ciência da Administração, a História, a Etnografia, a Matemática, dentre outras ciências, que primeiramente demonstraram interesse em refletir e construir as teorias do conflito (LUCENA FILHO, 2012).

Quando se estuda o conflito, embora existam diversas abordagens acerca do tema, é certo que é perfeitamente possível notar que são as alterações notadas no comportamento dos indivíduos e da sociedade em geral que fazem com que os conflitos aconteçam e que, inclusive,

\footnotetext{
${ }^{5}$ A respeito da moderna teoria dos conflitos, é pertinente mencionar, dentre seus expoentes, Honneth (2008), para quem é necessário visualizar as formas com que os indivíduos e também os grupos sociais inserem-se na sociedade democrática moderna, sendo que a formação da identidade, segundo o autor, é um processo de luta entre os sujeitos pelo mútuo reconhecimento em relação aos parceiros de interação. Honneth, aliás, é importante não apenas por seu pensamento a respeito dos conflitos como também quando pensa a reciprocidade, assim como faz Levinas. Contudo, o pensamento de ambos distingue-se, sobretudo, porque, enquanto Honneth trata da questão da luta por reconhecimento, entendendo que o sujeito requer que algo de subjetivo nele seja reconhecido, por força de um reconhecimento que vem de fora para dentro, Levinas propõe que o sujeito deve perceber a subjetividade do outro e respeitá-la sem reduzir a subjetividade do outro à subjetividade do eu, e que, ao invés do sujeito requerer simplesmente o reconhecimento de sua subjetividade, o eu, para existir, deve antes reconhecer o outro.
}

Revista de Direito Brasileira | São Paulo, SP | v. 15 | n. 6 | p. 200 - 222 | set./dez. 2016 
aumentem e ganhem complexidade. No caso brasileiro, além disso, é preciso considerar que o poder público é um dos maiores litigantes, o que faz com que se possa até falar por aqui na existência de uma indústria gigantesca do conflito.

Nesse sentido, é necessário dizer que o fenômeno da sociedade de massa de que trata Ortega Y Gasset (2013), o qual guarda relação com o surgimento da produção em massa, característica do final do século XIX e início do século XX na Europa, proporcionou um acirramento dos conflitos que se tornaram cada vez mais complexos e, também, de massa.

Conflito, aliás, é definido pelo Dicionário Houaiss como sendo "profunda falta de entendimento entre duas ou mais partes; choque; enfrentamento; discussão acalorada; altercação" (HOUAISS, 2001, p. 797). Já, segundo o Dicionário Aurélio, a palavra conflito vem do latim conflictu e significa choque, embate, peleja; do latim confligere quer dizer lutar. Conflito, assim, quer dizer embate dos que lutam; discussão acompanhada de injúrias e ameaças; desavença; guerra; luta, combate; colisão, choque (FERREIRA, 1999).

Ocorre que o conflito, cuja compreensão é, na verdade, extremamente importante para o Direito, na cultura jurídica brasileira é entendido tradicionalmente sob o enfoque de sua resolução a partir de uma postura de confronto, adversarial, em que uma parte pretende superar a outra e vencê-la, rendê-la. Assim, uma parte argumenta e a outra já está pronta para contra-argumentar, mesmo que nenhuma das duas esteja dando real importância ao que a outra está argumentando, porquanto o interesse que prepondera de ambos os lados é apenas o de vencer, sem sequer ouvir o outro lado. Nesse sentido, é conveniente apontar que, por aqui, a solução dos conflitos tradicionalmente despreza a dialógica em prol da ênfase na dialética ${ }^{6}$, que está relacionada à superação de uma parte pela outra.

Enquanto sistema que é, o conflito é, por óbvio, um produto da sociedade, um processo de interação humana, que pode ocorrer entre pessoas, entre grupos ou pode ser social. O conflito pode ser também dividido em espécies, porquanto pode se apresentar na forma de conflito de valores, de informação, estruturais e de interesses, sendo que a distinção desses é importante para a mediação, que necessita compreender o conflito para solucioná-lo, transformando-o. A esse respeito diz Vasconcelos (2008) que o conflito de valores envolve diferenças relacionadas a posicionamentos ideológicos, morais, religiosos, enquanto o conflito de informação está ligado à informação dada de modo distorcido. Já para o referido autor os conflitos de interesses envolvem interesses que se chocam a respeito de bens e de direitos, ao passo que o conflito estrutural é um conflito que diz respeito a circunstâncias econômicas ou políticos.

Segundo Warat (2004), autor cujo pensamento é relevantíssimo para a reflexão acerca da mediação, por meio dessa o que se objetiva é operar um resgate entre as partes e também com relação ao futuro. Busca-se, dessa feita, realizar um resgate do ser humano, de seus valores e problemas. Na mediação preocupa-se com as pequenas coisas, e o papel do mediador é estimular as partes a se comunicarem e a se entenderem.

Para Warat (2004), os conflitos reais encontram-se no interior, no coração das pessoas, por isso há de se falar de uma nova linguagem para a mediação, uma linguagem nova, poética e cheia de sentimentos. Essa linguagem, que é oriunda do coração, é uma linguagem mágica, diferente da falada e da escrita, pois é uma linguagem sentida.

A mediação é, além do espaço que promove a formação de vínculos com a alteridade, um coração, porque é necessário sentir o conflito ao invés de pensar a respeito de seu significado. Assim, a mediação é muito mais do que uma forma de resolução não adversarial de disputas envolvendo o Direito, pois ela é capaz de estimular uma educação voltada para a paz, a efetivação da política da cidadania, dos direitos humanos e também da democracia (WARAT, 2001).

${ }^{6}$ É bom registrar que a dialética mencionada diz respeito ao conceito hegeliano de dialética (HEGEL, 2008). Revista de Direito Brasileira | São Paulo, SP | v. 15 | n. 6 | p. 200 - 222 | set./dez. 2016 
Assim sendo, a mediação é um espaço completamente distinto da jurisdição, pois é lugar de reencontro, diferentemente do que ocorre com a jurisdição, espaço no qual o que se pretende acima de tudo é decidir o caso, resolvendo o processo por meio de uma decisão que, acima de tudo, deverá transitar em julgado, consagrando ao final a segurança jurídica em detrimento da justiça.

A mediação, todavia, não pode de modo algum ser transformada em simples conciliação, tendo em vista que "um recurso alternativo ao Judiciário não pode ser concebido com as crenças e os pressupostos do imaginário comum dos juristas, pois, a mentalidade jurídica termina convertendo a mediação em uma conciliação" (WARAT, 2001, p. 89).

Sucede que, como a mediação é, acima de tudo, um espaço do encontro e do diálogo entre conflitantes, entre o eu e o outro, é o pensamento de Emmanuel Levinas sobre justiça e alteridade que pode funcionar mais adequadamente como aparato teórico para possibilitar que a mediação funcione efetivamente como mecanismo adequado de solução de problemas, de controvérsias ou de conflitos.

É por meio do diálogo, inclusive, que o mediador auxilia os participantes a descobrirem os verdadeiros conflitos e os seus reais interesses, para que possam trabalhar de modo cooperativo, com a finalidade de encontrar a melhor solução para o caso, solução essa que passa pela compreensão do que cada uma das partes está dizendo à outra, porque deverá, ao final, ser firmado um acordo consensual entre elas (EGGER, 2005).

Assim, a mediação deve perseguir o ideal de restaurar a paz e a harmonia entre os envolvidos, pois é papel do mediador trabalhar as relações entre as partes, para que a solução do conflito seja construída de forma espontânea a partir da vontade das partes que conseguem restabelecer o diálogo e solucionar seus conflitos mais profundos.

Não fosse o bastante, por meio do restabelecimento do diálogo e do debate entre as partes, a mediação pretende alcançar outros fins mais relevantes do que simplesmente a redução do número de processos existentes no país. Deve-se considerar, aliás, que a mediação nunca significará a cura para todos os males, porquanto não é o mecanismo adequado para a solução de todos os tipos de conflitos, embora seja certo que, todas as vezes em que a mediação for o mecanismo adequado, por meio dela será exercida a cidadania, quando o indivíduo escolherá, por vontade própria, solucionar o conflito em que se encontra inserido de modo livre, célere, pouco caro e eficaz.

A mediação pode, portanto, de modo pacífico, consensual e bastante distinto da jurisdição, dar a cada um o que é seu, o que é um modelo muito distinto do processo contencioso e adversarial brasileiro.

\section{A CONTRIBUIÇÃo DO PENSAMENTO DE EMMANUEL LEVINAS SOBRE ALTERIDADE E JUSTIÇA PARA A MEDIAÇÃO}

O contexto brasileiro atual, caracterizado pela preponderância do individualismo (Bortoloti; Flores, 2014), colabora para que a sociedade torne-se exacerbadamente conflituosa. A isso soma-se o fato de que o estado tem se ocupado em grande parte com a solução de conflitos por meio da jurisdição prestada pelo estado-juiz, num processo em que as partes são adversárias, devendo uma perder para a outra ganhar, sem que existissem, até muito recentemente, incentivos, por meio de políticas públicas, à solução pacífica e consensual de conflitos, sobretudo fora do processo. Tudo isso contribuiu de modo substancial para que hoje tramitem no Brasil pelo menos cem milhões de processos.

Nesse sentido, considerando que as relações humanas demonstram-se deterioradas pela preponderância dos interesses individuais sobre os públicos e coletivos, e que, por esse e por 
outros fatores, as pessoas não se mostram interessadas no debate, no diálogo e na solução consensual de seus problemas, conflitos e controvérsias, é perfeitamente possível esperar que aqueles que estão em conflito dirijam-se o Judiciário, para que o estado-juiz decrete, após a análise das provas, dos fatos e do direito, ouvidas as partes, quem ganha e quem perde.

É esse o ambiente no qual a mediação, enquanto mecanismo de solução pacífica e consensual dos conflitos, dentro e fora do processo, deve ganhar cada vez mais importância no ordenamento jurídico brasileiro, não somente em virtude da crise do Poder Judiciário, abarrotado de demandas e de recursos, inclusive nos tribunais superiores, como também em decorrência da finalidade, do método e da vinculatividade da mediação. É perfeitamente pertinente acrescentar a isso o fato de que as consequências da cultura da litigiosidade e da adversariedade evidentemente predominante no Brasil impõem uma mudança paradigmática na solução dos conflitos, sendo que nessa mudança a mediação apresenta-se como um mecanismo indispensável de solução de conflitos e de pacificação social.

Quando se considera que o novo Código de Processo Civil, orientado pelos ditames constitucionais, abriu-se para os mecanismos pacíficos e consensuais de solução de conflitos, dentro ou fora do processo, isso permite vislumbrar e refletir acerca da referida importância que a mediação, em particular, já conquistou e o quanto a potencialização de seu uso é imprescindível.

É exatamente a esta altura que cabe afirmar que o pensamento de Emmanuel Levinas sobre justiça e alteridade funciona perfeitamente como aparato teórico para a plena compreensão da mediação e a potencialização de seu uso. E essa afirmação tem como fundamento o fato de que a mediação deve ser um espaço do diálogo entre o eu e o outro, embora não seja o locus de um encontro qualquer entre o eu e o outro, pois o outro não pode estar reduzido ao eu, não podendo também a mediação ser uma simples conciliação nem estar restrita aos limites da jurisdição estatal, preocupada que é a derradeira com a resolução do processo, sem se ocupar propriamente com a transformação da relação entre as partes, com seus sentimentos, com a relação entre elas, e, também, com a construção de uma solução que evite conflitos futuros.

Fora da tradição filosófica ocidental na qual preponderou o eu como unidade totalizante, que não admitia o enfrentamento e a consideração da diversidade entendida enquanto abertura para o outro, tradição essa que surge na passagem da Idade Média para a Idade Moderna e chega à atualidade, sendo precedida pelo domínio do Ser nas Idades Antiga e Média, Levinas (2015) traz a preocupação com a Filosofia vista a partir do eu rumo ao outro, do eu rumo ao outro.

Assim, o pensamento de Levinas situa-se fora da tradição filosófica moderna ocidental que, irreconciliavelmente, distanciou o eu do outro e a consciência do mundo.

Dando ao infinito a ideia de orientação metafísica para a ética por ele pensada, Levinas (2015) dispõe que é a ética a linguagem mais adequada para possibilitar a expressão da verdade da subjetividade humana. Para o filósofo, é a subjetividade erguida como radicalidade ética que possibilita a superação da filosofia do mesmo, a superação do outro reduzido ao mesmo, a superação da totalidade, de modo que se pode abrir ao infinito, abandonando-se o anonimato e a impessoalidade do Ser, para ir ao encontro do outro, o que para Levinas (2015) é a verdadeira Metafísica.

Levinas (2015) pensa que na justiça está a originária última justificação do discurso filosófico. Para o autor, a Ética, e não a Ontologia, é a Filosofia primeira. É no face-a-face humano que se irrompe todo sentido. Diante do rosto do outro, o sujeito descobre-se responsável e nele surge a ideia o infinito.

Em dois momentos Levinas (2015) pensa a respeito da justiça, num primeiro a justiça é compreendida enquanto sinônimo de responsabilidade do eu em relação ao outro, ao passo que, adiante, Levinas (2011) distingue a responsabilidade do eu perante o outro e a responsabilidade do eu perante os outros, a qual é, então, entendida como sendo justiça. 
Segundo Levinas (2015), a justiça deve perpassar necessariamente a ética e a conscientização a respeito da reciprocidade de responsabilidade do eu para com o outro. A justiça em Levinas (2015) é a infinita responsabilidade do eu com os outros, que decorre do face-a-face entre eles.

A ideia de alteridade em Levinas (2015) presta-se, portanto, a potencializar o instituto da mediação, pacificando as relações de modo mais profundo, e, portanto, indo além da simples resolução do caso. Nesse sentido, é pertinente reforçar que, depois de construir uma crítica radical à Ontologia, Levinas (2015) afirma que a ética é a filosofia primeira, que se traduz na responsabilidade incondicional e irrecusável não só pelo outro, mas também por todos os outros, o que implica um rompimento com o egoísmo. Sua filosofia ajuda a refletir, portanto, sobre a importância da alteridade, que nos leva, por meio da educação e da ética, a uma vida mais humana no mundo contemporâneo, repleto que é de conflitos e individualista. Dessa forma, torna-se possível perceber a influência que sua ética da alteridade exerce sobre o homem contemporâneo, exigindo dele a responsabilidade para com o(s) outro(s).

Em Levinas (2015), a responsabilidade antecede a liberdade. Isso é muito caro ao pensamento levinasiano, no qual o outro antecede o eu. A liberdade do eu esbarra na responsabilidade pelo outro, que é imposta ao eu. O rosto de que fala o filósofo é presença viva, é expressão. A experiência absoluta é a revelação e manifestação de um rosto para além da forma. Acolher o outro significa colocar a liberdade do eu em questão. Levinas (2015) fala, portanto, da ética da responsabilidade.

Levinas (2015) convida a todos à superação da individualidade. Para ele, o rosto não pode ser adequado conforme a visão, ele não será captado em sua totalidade, porque o rosto leva além, ele conduz ao infinito. É o primeiro contato como o rosto o instante em que se compreende o outro, o que é uma atitude ética. E no momento em que o rosto se desvela é o momento em que surge o mandamento "não cometerás assassínio" (LEVINAS, 2015, p. 193), sendo que o rosto fala, porque é ele que torna possível e começa o discurso (LEVINAS, 2015).

$\mathrm{O}$ rosto do outro revela o infinito. $\mathrm{O}$ outro, aliás, precede o eu, o que até então era impensável dentro da tradição filosófica ocidental, de modo que aqui está evidenciada, exposta mesmo, a imensa importância do pensamento levinasiano (LEVINAS, 2015).

A responsabilidade, para o autor, não guarda relação com a obrigação de assistir a alguém, pois a responsabilidade para com os outros é extensão do próprio ser (LEVINAS, 2015).

Levinas (2015) privilegia a Metafísica em detrimento da Ontologia, porque o autor entende que a Ontologia foi um projeto de intelegibilidade e de dominação que repousou sobre a repressão do outro, sobre a redução do outro ao mesmo, pois o outro é neutralizado e cai sem voz e despido de sua individualidade. Essa neutralização do outro acontece quando o outro é tema ou objeto de uma redução do mesmo. A Metafísica descobre, assim, a transcendência do outro, enquanto a Ontologia debruça-se apenas sobre a imanência do mesmo.

Levinas não refletiu sobre a mediação, mas seu pensamento é o mais importante aparato teórico para uma mudança de paradigma na cultura demandista brasileira. Pensar a mediação a partir do pensamento levinasiano deve significar que a solução consensual de determinados conflitos, quando construída por meio da mediação, que então deverá se apresentar para o caso concreto como o mecanismo mais adequado, deve necessariamente significar a abertura para o outro, que não pode ser reduzido ao eu.

Levinas (2015) recusa a impossibilidade do reconhecimento do outro em sua diferença concretizada num mero exercício de redução do outro ao eu, que concebe o outro à sua imagem e semelhança. Assim, o autor demonstra a distância que até então existia entre o eu e o outro, quando compreende que é a questão ética que deve ser priorizada, realizando-se a completa inversão do primado do sujeito. 
A alteridade, ou seja, a compreensão do outro em Levinas (2015) exige que o outro continue sendo sempre o outro e não simples imagem do eu. O outro como alteridade não pode ser conceituado, mas permanece concreto. O outro, portanto, é o absolutamente outro, Outrem. O outro não é representação do eu, ele é o caminho do infinito.

O pensamento de Levinas permite compreender a mediação em sua plenitude, porque nela a solução do problema, do conflito ou da controvérsia não pode significar a redução do outro ao eu, devendo o outro permanece sempre o outro. $\mathrm{O}$ outro deve ser reconhecido como outro concreto. A relação constitui o sujeito, e na relação com o outro concreto o sujeito é constituído. Essa relação da alteridade é denominada de ética em Levinas. A ética é entendida como muito mais do que um código ou princípios morais de ação. A ética é, nesse sentido, a filosofia primeira. A ética é posta como a essência do discurso (Levinas, 2015).

No pensamento de Levinas (2015) a relação entre o eu e o outro não é uma opção da vontade livre do sujeito, mas a condição que constitui o modo de ser dessa vontade. A relação com o outro, que é prévia à vontade, interpela a liberdade do eu, porque toda relação é interpelação. Essa relação afeta, enriquece e ao mesmo tempo é desafiadora. $\mathrm{O}$ eu torna-se responsável quando o outro é necessitado, sendo que a responsabilidade pelo outro aparece para o eu na relação antes que o eu possa evitá-la.

Em Levinas (2015) à totalidade opõe-se o infinito. O infinito é a presença de um ser que não é fechado na esfera do mesmo, e essa presença vai transborda, fixa a sua condição de infinito. A ideia de infinito, por sua vez, vai muito além dos poderes do eu e manifesta-se na epifania do rosto, o que significa que se impõe para além da forma. O rosto abre o discurso original, cuja primeira palavra é obrigação que não se permite evitar. O pretenso escândalo do rosto supõe a identidade tranquila do mesmo, a segurança em si próprio.

Para Levinas (2015) é no acolhimento do rosto que a vontade abre-se para a razão.

Assim, a ideia de infinito opõe-se à ideia de totalidade. Levinas critica a totalidade, ou seja, a exigência de saber absoluto na filosofia ocidental e a visão totalizante que caracteriza todos os grandes sistemas filosóficos. Para o autor, a experiência essencial encontra-se no face-aface dos seres humanos, na relação ética (LEVINAS, 2015).

O outro é a razão que fundamenta o eu. Isso é, impõe-se notar, radicalmente novo. E essa razão que dialoga quando do confronto entre dois seres não é abstrata no pensamento levinasiano (LEVINAS, 2015).

A mediação fundada no pensamento de Levinas sobre a alteridade deve possibilitar o encontro e o diálogo do eu com o outro, que não deixará de ser o outro, em busca da restauração e da transformação da relação existente entre os conflitantes, de sorte que o eu e o outro devem se encontrar sem que o primeiro pretenda reduzir o segundo ao que aquele propriamente é.

E mais, a mediação, mais do que a jurisdição, deve propiciar, a fim de trazer a justiça para o Direito, o reconhecimento do estranho, do que não tem voz, daquele que causa náusea no outro, ou seja, a mediação presta-se ao reconhecimento do não identificado, daquele que, sem ser reduzido ao eu, construirá com esse último uma solução pacífica e consensual para seus conflitos.

É perfeitamente possível afirmar que a mediação almeja uma pacificação social qualificada, se pensada a partir da filosofia de Levinas, porque por meio dela busca-se o restabelecimento do diálogo entre as partes, o debate, a solução do conflito, a prevenção de conflitos futuros e a restauração da relação entre as partes de modo transformado. Para isso é preciso partir do pressuposto de que o ser é o ser para o outro (LEVINAS, 2015).

Levinas (2015), ao tratar da epifania do rosto, rompe definitivamente com as teorias liberais de justiça, ele busca uma justiça relacionada aos indivíduos concretos, uma justiça que é um árbitro permanentemente disposto a ouvir e que tem um compromisso ético. Em Levinas (2015) a justiça é a responsabilidade pela vida decorrente do encontro do eu com o outro, do face-a-face, a epifania que o rosto do outro provoca. 
Isso evidentemente altera tudo que até então havia sido pensado sobre a justiça e que serve perfeitamente à mediação enquanto oportunidade de encontro do eu com o outro. A mediação como mecanismo de solução de conflito fundada no pensamento levinasiano implica mudança de paradigma. É realizar a justiça porque não é possível omitir-se diante da negação da alteridade. Assim, diferentemente das concepções liberais de justiça, em Levinas é o estado que deve ser orientado para a justiça, ao invés de se ter uma concepção de justiça que assegura a existência do estado.

Na mediação os conflitantes devem construir a solução para o conflito considerando que o ser só é ser para o outro (LEVINAS, 2015).

\section{CONCLUSÃO}

É necessário reconhecer que a abertura do novo Código de Processo Civil para os meios adequados de solução de conflitos tem fundamento constitucional e demanda do poder público políticas públicas que assegurem a pacificação social por meio da solução de problemas, de controvérsias e de conflitos especialmente fora do processo, que sejam céleres, baratas e acima de tudo eficazes.

A mediação, que não é medicamento para todos os males, é um dos importantes mecanismos de solução de conflitos, sobretudo fora do processo, o qual, bem compreendido e realizado, é capaz de construir soluções para os conflitos que possibilitem uma pacificação social qualificada pelo restabelecimento do diálogo, pela reconstrução das relações humanas e pela prevenção de futuros conflitos, de sorte que ter acesso ao mecanismo da mediação é ter acesso à justiça material.

Aliás, a mediação, que nunca poderá ser reduzida à conciliação, deve permitir um encontro ético entre os envolvidos, que venha a possibilitar o restabelecimento do diálogo e a restauração da relação entre o eu e o outro que nunca poderá ser reduzido ao eu. Mais do que isso, a mediação deverá contribuir para a construção da autonomia e para o exercício da cidadania por parte dos próprios conflitantes.

Compreender a mediação e solucionar conflitos por meio dela exige responsabilidade na concepção levinasiana, uma responsabilidade ética do eu para com o outro.

O incentivo por meio de políticas públicas à mediação, quando essa apresenta-se como o mecanismo adequado para a solução dos conflitos, implica, por tudo que foi dito sobre a mediação e a cultura jurídica brasileira, uma mudança radical de paradigma de enfrentamento dos conflitos no ordenamento jurídico nacional, no qual, historicamente, o modelo hegemônico de solução de disputas sempre foi um dos grandes responsáveis por alimentar uma cultura do conflito e de sua solução por decreto judicial.

Assim, tendo o pensamento de Levinas como aparato teórico, a consideração e a promoção da alteridade pensada pelo filósofo e o resgate de vínculos destroçados pelo conflito na mediação devem prestar-se a trazer para o Direito uma concepção de justiça sociopolítica radicalmente distinta de todas as concepções até então concebidas, porque a construção da solução dos conflitos por meio da mediação deve ser compreendida como a realização da justiça entendida como responsabilidade do eu perante o outro e responsabilidade do eu perante os outros, lembrando sempre que, para Levinas (2015), a justiça deve perpassar necessariamente a ética e a conscientização a respeito da reciprocidade da responsabilidade do eu para com o outro, sendo a justiça, na verdade, uma infinita responsabilidade do eu com os outros. 


\section{REFERÊNCIAS}

BRASIL. Código de Processo Civil. Lei n. ${ }^{\circ} 13.105$, de 16 de março de 2015.

BRASIL. Constituição Federal da República Federativa do Brasil 1988.

Conselho Nacional de Justiça. Justiça em números 2015. Brasília, 2015. Disponível em <http://www.cnj.jus.br/programas-e-acoes/pj-justica-em-numeros>. Acesso em 03 e maio de 2016.

Conselho Nacional de Justiça. Resolução n. ${ }^{\circ}$ 125, de 29 de novembro de 2010. Dispõe sobre a Política Judiciária Nacional de tratamento adequado dos conflitos de interesses no âmbito do Poder Judiciário e dá outras providências. Disponível em: < http://www.cnj.jus.br/busca-atosadm?documento=2579>. Acesso em: 31 março de 2016.

Conselho Nacional de Justiça. Resolução n. ${ }^{\circ} 225$, de 31 de maio de 2016. Dispões sobre a Política Nacional de Justiça Restaurativa no âmbito do Poder Judiciário e dá outras providências. Disponível em file://C:/Users/Marques/Google\%20Drive/Resolução\%20CNJ\%20justiça\%20restaurativa.pdf>. Acesso em 06 de junho de 2016.

Conselho Nacional do Ministério Público. Resolução n. ${ }^{\circ} 118$, de $1^{\circ}$ de dezembro de 2014. Dispõe sobre a Política Nacional de Incentivo à Autocomposição no âmbito do Ministério Público e dá outras providências. Disponível em http://www.cnmp.mp.br/portal_2015/images/Normas/Resolucoes/Resolu\%C3\%A7\%C3\%A3o_n \%C2\%BA_118_autocomposi\%C3\%A7\%C3\%A3o.pdf>. Acesso em: 31 de março de 2016.

Conselho Nacional do Ministério Público. Manual de negociação e mediação para membros do Ministério Público. 2a ed. Brasília: CNMP, 2015.

BORTOLOTI, J C Kraemer; FLORES, NC. Direito e $(\mathrm{m})$ alteridade: o individualismo exacerbado e a abstração dos direitos humanos. Direito, Estado e Sociedade, Rio de Janeiro, n. ${ }^{\circ}$ 43, p. 119 a $134 \mathrm{jul} / \mathrm{dez}, 2013$.

CAPPELLETTI, Mauro; GARTH, Bryant. Acesso à justiça. Trad. Ellen Gracie Northfleet. Porto Alegre: Sérgio Antônio Fabris Editor, 1988.

Mauro. Os métodos alternativos de solução de conflitos no quadro do movimento universal do acesso à justiça. Revista de Processo, São Paulo, ano 19, n. 74, abr-jun 1994.

CONSTANTINO, Cathy A.; MERCHANT, Christina Sickles. Designing conflict management systems. $1^{\mathrm{a}}$ ed. São Francisco: Jossey-Bass, 1996.

DEUTSCH, Moron. A resolução do conflito: processos construtivos e destrutivos. In: AZEVEDO, André Gomma de (org.). Estudos em arbitragem, mediação e negociação. Brasília: Brasília Jurídica, 2004. 3 v.

DIDIER JR., Fredie. Curso de Direito Processual Civil I - Teoria Geral do Processo e Processo de Conhecimento. $11^{\mathrm{a}}$ ed. Salvador: JusPodivm, 2009. 1 v. 
ECONOMIDES, Kim. Lendo as ondas do Movimento de Acesso à Justiça: epistemologia versus metodologia? In: PANDOLFI, Dulce et al. (orgs). Cidadania, justiça e violência. Rio de Janeiro: Ed. Fundação Getúlio Vargas, 1999. p. 61-76. Disponível em <http://gajop.org.br/justicacidada/wp-content/uploads/Lendo-as-Ondas-do-Movimento-deAcesso-aa-Justica.pdf $>$. Acesso em 12 de março de 2016.

EGGER, Ildemar. $O$ papel do mediador. 2005. Disponível em < http://www.egger.com.br/ie/mediacao.htm>. Acesso em 02 de março de 2016.

. EGGER, Ildemar. Justiça Privada: formas alternativas de resolução de conflitos. Revista JUSTILEX, Brasília, ano I, n. ${ }^{\circ}$ 12, dez 2002.

ENTELMAN, Remo F. Teoría de conflictos: hacia un nuevo paradigma. Barcelona: Gedisa, 2002.

FERREIRA, Aurélio Buarque de Holanda. Dicionário Eletrônico Aurélio Século XXI. [CDROM] versão 3.0. Rio de Janeiro: Editora Nova Fronteira e Lexikon Informática, 1999.

GALANTER, Marc. Introduction: Compared to what? Assessing the quality of dispute processing. Denver University Law Review, n. 66, 1989. Disponível em < http://marcgalanter.net/Documents/papers/scannedpdf/comparedtowhat.pdf>. Acesso em: 03 de maio de 2016.

GARCEZ, José Maria Rossani. Negociação. ADRS. Mediação. Conciliação e Arbitragem. Rio de Janeiro: Lumen Juris, $2^{\text {a }}$ edição, revista e ampliada, 2003.

GAVRONSKI, Alexandre Amaral. Técnicas extraprocessuais de tutela coletiva - a efetividade da tutela coletiva fora do processo judicial. São Paulo: Ed. Revista dos Tribunais, 2010.

GOULART, Juliana Ribeiro; GONÇALVES, Jéssica. Conheça os principais modelos de Mediação de Conflitos. 2016. Disponível em < http://emporiododireito.com.br/conheca-osprincipais-modelos-de-mediacao-de-conflitos-por-juliana-ribeiro-goulart-e-jessica-goncalves/> . Acesso em 03 de março de 2016.

HEGEL, Georg Wilhelm Friedrich. Fenomenologia do espírito. $2^{\text {a }}$ ed., Petrópolis: Vozes, 2008.

HONNETH, Axel. Luta por reconhecimento: por uma Gramática Moral dos Conflitos Sociais. Lisboa: Edições 70, 2011.

HOUAISS A, Villar MS. Dicionário Houaiss da língua portuguesa. 1a . ed. Rio de Janeiro: Objetiva, 2001.

INSTITUTO BRASILEIRO DE GEOGRAFIA E ESTATÍSTICA. Resolução n. ${ }^{\circ}$ 4, de 26 de $\begin{array}{lllll}\text { agosto de } & 2015 . & \text { Disponível }\end{array}$ http://pesquisa.in.gov.br/imprensa/jsp/visualiza/index.jsp?jornal=1\&pagina=98\&data=28/08/201 5>. Acesso em 02 de junho de 2016. 
JUNQUEIRA, Eliane Botelho. Visões alternativas do direito no Brasil. Revista Estudos Históricos, Rio de Janeiro, n. ${ }^{\circ}$ 18, 1996. p.1-14.

KESSLER, Gladys; FINKELSTEIN, Linda J. The Evolution of Multi-door Courthouse. Catholic University Law Review. Issue 3, $37 \quad \mathrm{v}, \quad$ 1998. Disponível em http://scholarship.law.edu/cgi/viewcontent.cgi?article=1897\&context=lawreview. Acesso em: 02 de maio de 2016.

LEE, Joe. The evolving " $A$ " in $A D R$. Disponível em http://kluwermediationblog.com/2012/03/14/the-evolving-a-in-adr/. Acesso em 04 de maio de 2016.

LEVINAS, Emmanuel. De otro modo que ser o más allá de la esencia. $5^{\mathrm{a}}$ ed. Salamanca: Ediciones Sígueme, 2011.

. Ética e Infinito. Lisboa: Edições 70. 1982.

. Humanismo do Outro Homem. Petrópolis: Vozes. 2006.

. Totalidade e infinito. Lisboa: Edições 70, 2015.

LUCENA FILHO, Humberto Lima de. A constitucionalização da solução pacífica de conflitos na ordem jurídica de 1988. Rio Grande do Norte: Universidade Federal do Rio Grande do Norte, 2012a, 162 p., Dissertação (Mestrado em Direito) - Programa de Pós-Graduação em Direito, Centro de Ciências Sociais Aplicadas, Universidade Federal do Rio Grande do Norte, Natal, $2012 . \quad$ Disponível em https://repositorio.ufrn.br/jspui/bitstream/123456789/13943/1/HumbertoLLF_DISSERT.pdf>. Acesso em 03 de maio de 2016.

OLIVEIRA, Lauro Ericksen Cavalcanti. A teoria geral dos conflitos e a sua compreensão como um fenômeno sócio-jurídico: os planos objetivo, comportamental e anímico dos conflitos. Revista da Escola Superior da Magistratura Trabalhista da Paraíba. João Pessoa, Ano IV - n. ${ }^{\circ} 4$, outubro de 2011, p.143-164.

ORTEGA Y GASSET, José. A rebelião das massas. Ed. Ridendo Castigat Mores, 2001. Disponível em < http://livros01.livrosgratis.com.br/cv000060.pdf>. Acesso em 03 de abril de 2016.

PINHO, Humberto Dalla Bernardina de. Teoria Geral da Mediação. Rio de Janeiro: Lumen Juris, 2008.

RIEGO, Cristian; LILLO, Ricardo. Las Unidades de Justicia Vecinal en Chile y sus modelos en la experiencia de los Estados Unidos de Norteamérica. Revista de Derecho de la Pontificia Universidad Católica de Valparaíso, n. 43, Valparaíso, 2014. Disponível em <http://www.scielo.cl/scielo.php?pid=S0718-68512014000200010\&script=sci_arttext $>$. Acesso em: 02 de maio de 2016.

SANTIAGO, Marcus Firmino. Uma abordagem diferenciada acerca da tutela jurisdicional. ABDPC artigos. São Paulo, 2009. Disponível em: http://www. abdpc.org. 
br/abdpc/artigos/Marcus\%20Firmino\%20Santiago-formatado.pdf. Acesso em 10 de março de 2016.

SILVA, Paula Costa e. A Nova Face da Justiça: os meios extrajudiciais de resolução de controvérsias. Lisboa: Coimbra Editora, 2009.

TARTUCE, Fernanda. Mediação nos Conflitos Civis. Rio de Janeiro: Forense, 2008.

VASCONCELOS, Carlos Eduardo de. Mediação de conflitos e práticas restaurativas. São Paulo: Método, 2008.

WARAT, Luis Alberto. O ofício do mediador. Florianópolis: Habitus. 2001.

Luis Alberto. Surfando na pororoca: o ofício do mediador. Florianópolis: Fundação Boiteux, 2004. 